\title{
DAMPAK PENYEBARAN VIRUS CORONA (COVID 19) TERHADAP PEMBERDAYAAN UMKM DI KABUPATEN SUKOHARJO
}

\author{
Ika Swasti Putri*, Yuniatin Trisnawati DKW* \\ *Prodi Akuntansi, STIE Adi Unggul Bhirawa Surakarta \\ Email : ikakame@gmail.com
}

\begin{abstract}
The existence of COVID-19 as a pandemic around the world resulted in the economic road becoming disturbed, especially in the field of SMES. The current impact is the disruption of the economic process in the MSME sector. In addition, the disruption of health and restriction for the economy outside the region also become the impact that the population of the SME community. However, there is a positive impact that can be gained, which is the more creative of SMES actors to get around the current situation with a growing creativity. The government is also anticipating how to keep the SME actors who want to remain in the middle of pandemic so that the synergy between SMES and government is well established.
\end{abstract}

Keywords: MSMES, COVID-19, economy

\section{PENDAHULUAN}

Pembangunan perekonomian dalam masyarakat tidak bisa dilepaskan dari usaha di bidang mikro, kecil, dan menengah. Hal ini dikarenakan usaha masyarakat mampu menyerap tenaga kerja yang ada di sekitarnya sehingga mampu mengurangi pengangguran sekaligus memberdayakan sumber daya yang ada di lingkungan usaha tersebut. Selain itu, usaha mikro, kecil, dan menengah (UMKM) juga memiliki peran penting dalam hal pemerataan pembangunan karena UMKM memegang peranan penting dalam perputaran ekonomi di suatu daerah. Ketika suatu daerah mampu memajukan UMKM, maka kemajuan perekonomian daerah tersebut akan semakin baik karena perputaran uang di daerah tersebut semakin cepat sehingga perekonomian di daerah tersebut semakin terangkat. Selain itu, keberadaan UMKM merupakan sarana bagi masyarakat di desa untuk mengeluarkan ide-ide kreatif sekaligus membuka lapangan kerja bagi masyarakat di daerahnya. UMKM sebagai usaha kreatif juga dapat dijadikan sarana sebagai pengentas pengangguran dan memberikan lapangan kerja (Darwanto, 2013)
Terkait dengan hal tersebut, Sebagai industri yang mengandalkan kreativitas dan keterampilan dari seseorang atau individu, industri kreatif menawarkan suatu kreativitas yang dapat mengedukasi masyarakat untuk tidak takut memulai usaha sendiri sekaligus menciptakan lapangan pekerjaan. Saat ini permasalahan yang cukup klise di tengah masyarakat adalah banyaknya pengangguran, sehingga ekonomi kreatif merupakan suatu aspek yang harus dikembangkan di Indonesia. Adapun berdasarkan omsetnya, UMKM dapat diklasifikasikan sebagai berikut.

Tabel 1

Perincian Usaha UMKM

\begin{tabular}{|l|l|l|l|}
\hline No & Usaha & $\begin{array}{l}\text { Kriteria } \\
\text { Asset }\end{array}$ & $\begin{array}{l}\text { Kriteria } \\
\text { Omset }\end{array}$ \\
\hline 1 & $\begin{array}{l}\text { Usaha } \\
\text { Mikro }\end{array}$ & $\begin{array}{l}\text { Maks. 50 } \\
\text { Juta }\end{array}$ & $\begin{array}{l}\text { Maks. 300 } \\
\text { Juta }\end{array}$ \\
\hline 2 & Usaha Kecil & $\begin{array}{l}>50 \text { Juta }- \\
\text { 500 Juta } 300 \text { Juta }- \\
\text { 2,5 Miliar }\end{array}$ \\
\hline 3 & $\begin{array}{l}\text { Usaha } \\
\text { Menengah }\end{array}$ & $\begin{array}{l}\text { > 500 Juta }- \\
\text { 10 Miliar }\end{array}$ & $\begin{array}{l}>\text { 2,5 Miliar - } \\
\text { 50 Miliar }\end{array}$ \\
\hline
\end{tabular}

Di Sukoharjo, UMKM merupakan bentuk usaha rakyat yang menjadi sumber pendapatan di daerah tersebut. Dalam hal ini, UMKM menjadi salah satu kegiatan perekonomian masyarakat yang menjadi tonggak pembangunan perekonomian yang cukup penting di Kabupaten Sukoharjo. Alasannya adalah permasalahan 
terbatasnya lapangan kerja akan dapat teratasi sekaligus mendorong pertumbuhan ekonomi di daerah yang menjadi komoditi suatu UMKM. Di Sukoharjo sendiri terdapat banyak UMKM yang tersebar di 12 kecamatan dengan berbagai macam jenis usaha seperti kuliner, mebel, tekstil, dan lain-lain. Keberadaan UMKM ini menjadi mata pencaharian penduduk sekaligus menjadi sarana pengembangan kreativitas penduduk. Hal ini dikarenakan pada dasarnya UMKM akan meningkatkan perekonomian sehingga kesejahteraan masyarakat akan meningkat (Suharto, 2009).

Akan tetapi, saat ini jalannya UMKM di Kabupaten Sukoharjo mengalami hambatan dikarenakan merebaknya virus corona atau COVID 19. Virus ini merupakan virus yang berasal dari Wuhan, China yang menjadi pandemi di seluruh dunia. Perputaran ekonomi di seluruh dunia menjadi terganggu sehingga menyulitkan masyarakat untuk menjalankan kegiatannya sehari-hari. Keberadaan Virus Corona ini tentu saja mengakibatkan perekonomian lumpuh. Selain itu, berdasarkan data yang dihimpun oleh Kementerian Kesehatan Indonesia, terdapat sekitar 3.293 orang yang diduga mengalami gejala coronavirus (Kemenkes, 2020) angka ini mengakibatkan pemerintah memberlakukan social dan physical distancing untuk menekan penularan Coronavirus. Penetapan kebijakan social dan physical distancing ini mengakibatkan jalannya UMKM di Kabupaten Sukoharjo menjadi terhambat.

Terpengaruhnya UMKM yang selama ini merupakan salah satu sumber pendapatan masyarakat akibat Coronavirus menjadi latar belakang peneliti untuk meneliti studi tentang dampak coronavirus terhadap jalannya UMKM di Kabupaten Sukoharjo. Peneliti melakukan studi untuk menganalisis dampak coronavirus terhadap jalannya UMKM di Kabupaten Sukoharjo.

\section{METODE PENELITIAN}

Penelitian kualitatif merupakan jenis penelitian yang akan digunakan dalam penelitian. Adapun para pelaku UMKM Kabupaten Sukoharjo menjadi objek dari penelitian ini. Pengambilan sampel dilakukan dengan cara mengambil data-data yang penting terkait dengan penelitian atau purposive sampling dimana pengambilan sampel dilakukan berdasar pada kriteria tertentu sesuai dengan tujuan penelitian. Kriteria yang diambil dalam sampel penelitian ini adalah UMKM yang berada dilingkungan Kabupaten Sukoharjo. Dalam penelitian ini lebih menitikberatkan data primer. Data wawancara dalam penelitian ini diperoleh dari wawancara kepada pelaku UMKM di Kabupaten Sukoharjo sehingga data tersebut menjadi data primer. Di samping itu, keberadaan jurnal, buku, dan laporan juga menjadi beberapa data sekunder yang dibutuhkan dalam penelitian ini. Dalam penelitian ini, digunakan teknik analisis dari Miles dan Huberman (1992) melalui analisis model interaktif. Analisi ini meliputi reduksi data, penyajian data, dan penarikan kesimpulan

\section{HASIL PENELITIAN}

Pemberdayaan UMKM menjadi salah satu fokus pengembangan oleh Pemkab Sukoharjo. Di Sukoharjo sendiri, terdapat beberapa UMKM yang terdapat di 12 kecamatan yang tersebar di seluruh Sukoharjo. Adapun perinciannya adalah sebagai berikut.

Tabel 2

Perincian UMKM di Kabupaten Sukoharjo

\begin{tabular}{|c|c|c|}
\hline No & Kecamatan & Jumlah UMKM \\
\hline 1 & Kecamatan Tawangsari & 36 UMKM \\
\hline 2 & Kecamatan Kartasura & 42 UMKM \\
\hline 3 & Kecamatan Bulu & $21 \mathrm{UMKM}$ \\
\hline 4 & Kecamatan Grogol & 40 UMKM \\
\hline 5 & Kecamatan Weru & 12 UMKM \\
\hline 6 & Kecamatan Sukoharjo & 31 UMKM \\
\hline 7 & Kecamatan Polokarto & 36 UMKM \\
\hline 8 & Kecamatan Bendosari & 19 UMKM \\
\hline 9 & Kecamatan Nguter & 13 UMKM \\
\hline 10 & Kecamatan Gatak & 18 UMKM \\
\hline 11 & Kecamatan Mojolaban & 11 UMKM \\
\hline 12 & Kecamatan Baki & 26 UMKM \\
\hline \multicolumn{2}{|r|}{ Jumlah } & 305 UMKM \\
\hline
\end{tabular}


Berdasarkan tabel tersebut, terlihat bahwa UMKM terdapat di tiap kecamatan di Kabupaten Sukoharjo. Persebaran ini diperkuat dengan pernyataan dari Koordinator UMKM Kabupaten Sukoharjo yang menyatakan bahwa pemberdayaan UMKM di 12 kecamatan di Sukoharjo merupakan prioritas dari Pemkab Sukoharjo saat ini sehingga pemberdayaan UMKM adalah salah satu aspek yang harus ditingkatkan.

Sebagaimana diketahui di awal tahun 2020, dunia kesehatan digemparkan dengan adanya COVID 19 yang berawal dari laporan Badan Kesehatan Dunia (WHO) yang mengonfirmasi bahwa ditemukan virus jenis baru di Kota Wuhan, Hubei, China yang mengakibatkan banyak warganya menderita pneumonia. Kasus ini menjadi berbahaya karena tidak diketahui etiologi dari virus ini dan penyebarannya pun sangat cepat. Etiologi yang tidak diketahui ini kemudian dikenal menjadi novel coronavirus. Karena penyebarannya sangat cepat, kasus ini menyebar hingga ke luar China dan mengakibatkan terjadinya kematian di luar China. Atas dasar itulah maka WHO menetapkan COVID-19 sebagai kejadian luar biasa yang menjadi pandemi di seluruh dunia. Ketetapan ini mulai berlaku sejak WHO menetapkan nama dari novel coronavirus menjadi Coronavirus Disease (COVID-19) pada 12 Februari 2020 (Kemenkes, 2020).

Terkait dengan dampak penyebaran coronavirus, berdasarkan pendapat dari Koordinator UMKM Kabupaten Sukoharjo, penyebaran virus ini mengakibatkan terhentinya perekonomian UMKM. Ini tidak lepas dari physical distancing dan work from home yang dicanangkan pemerintah sehingga mengakibatkan roda perekonomian terganggu. Selain itu, ini juga tidak lepas dari status coronavirus yang sudah menjadi pandemi di seluruh dunia. Berdasarkan penelitian dari Symond (2009) pandemi ini mengharuskan strategi kesiapsiagaan dalam menghadapi segala kemungkinan yang terjadi. Pemerintah dan masyarakat sebagai stakeholder perlu bersinergi untuk menciptakan situasi yang kondusif sekaligus melenyapkan Virus Corona yang saat ini menjadi pandemi di seluruh dunia.

Ketua UMKM Kabupaten Sukoharjo mengatakan bahwa Dampak lain yang cukup terlihat adalah terkendalanya kesehatan dari para pelaku UMKM, maka dari itu perlu untuk menghimbau para pelaku UMKM untuk disiplin mematuhi protocol kesehatan. Berdasarkan survei dari Kemenkes (2020) penularan manusia ke manusia pada virus MERS dan SARS sebelumnya, terjadi melalui bersin atau air liur dan benda yang mendapatkan sentuhan dari penderita, maka dapat disimpulkan penularan Virus Corona juga melalui proses yang sama. Berdasarkan hasil wawancara, banyak pelaku UMKM yang membatasi jam kerja atau bahkan menutup sementara usahanya karena takut terkena virus Corona. Berdasarkan pendapat Kemenkes (2020) dengan cuci tangan teratur dan mengikuti aturan dalam bersin dan batuk dapat mencegah penularan Virus Corona. Selain itu, diperlukan usaha untuk meminimalisir penyebaran virus dengan cara tidak menyentuh secara langsung hewan dengan berbagai jenis sekaligus menghindari kontak dengan orang-orang yang menderita batuk dan bersin. Pembuatan tempat khusus untuk mencegah dan mengendalikan infeksi virus juga dibutuhkan di fasilitas-fasilitas kesehatan. Ketua UMKM Sukoharjo berpendapat bahwa dampak lain saat pandemic ini adalah terbatasnya akses bagi para pelaku UMKM untuk memasarkan produknya ke luar kota ataupun ke luar negeri. Ini terlihat dari kebijakan pemerintah terkait dengan pengawasan di batas daerah ataupun batas negara. Saat ini pemerintah mewajibkan pengetatan terhadap semua jalur masuk dan keluar yang ada di semua batas daerah dan negara. Pemerintah juga mewajibkan adanya dokumen kontinjensi untuk mencegah sekaligus menghadapi pandemi yang terjadi saat ini sekalgus mengurangi 
risiko tertularnya virus. Dokumen tersebut berguna sebagai panduan untuk menghadapi COVID-19 yang saat ini sudah semakin meluas. Proses penyusunan dokumen tersebut membutuhkan koordinasi dan kesepakatan yang harus didukung oleh seluruh pihak yang terlibat di bidang transportasi darat, laut, dan udara serta dari pihak yang mengurus di bidang perbatasan antardaerah dan negara. Pengetatan yang dilakukan pemerintah ini merupakan tindak lanjut untuk membatasi penyebaran Coronavirus, akan tetapi pengetatan ini mengakibatkan para pelaku UMKM kesulitan mengembangkan usahanya. Maka ketua UMKM Sukoharjo mendorong para pelaku UMKM untuk memasarkan produknya secara online melalui platform e-commerce. Hal tersebut dilakukan agar produk mereka semakin luas pasarnya ditengah pandemic saat ini.

Dampak positif yang didapat dari UMKM sebagai industri kreatif membuat ekonomi kreatif yang dicanangkan pemerintah juga memiliki pengaruh di bidang sosial dan peningkatan ekonomi. Selain itu, pengembangan UMKM juga akan meningkatkan pendapatan dari kawasan tersebut sekaligus membuka lapangan pekerjaan. Dengan kata lain, selain mengambil keuntungan perluasan UMKM juga memiliki dampak untuk memberikan pengaruh baik pada daerah yang menjadi tujuan perluasan UMKM tersebut. (Prameswari, 2011). Ini juga diperkuat dengan pernyataan dari Ketua UMKM Kabupaten Sukoharjo yang menyatakan bahwa para pelaku UMKM sangat sulit memasarkan produknya di tengah pandemi Corona dikarenakan adanya pembatasan yang dilakukan pemerintah.

Dampak terakhir dari mewabahnya pandemi Corona adalah terpacunya para pelaku usaha UMKM untuk menciptakan peluang usaha baru untuk bisa bertahan dari krisis akibat corona. Para pelaku usaha juga berlomba-lomba memberikan inovasi bagi para pelanggannya agar tetap bisa melakukan work from home sekaligus membeli barang dari para pelaku UMKM Sukoharjo. Berdasarkan hasil wawancara, para pelaku UMKM sudah melakukan berbagai cara untuk menyiasati berbagai masalah yang terjadi, termasuk melakukan penjualan melalui media sosial atau situs jual beli daring, sehingga pelanggan bisa tetap membeli produk UMKM tanpa keluar dari rumah. Karena pada dasarnya, pertumbuhan ekonomi di suatu daerah akan mengalami kemajuan jika UMKM di daerah tersebut dikembangkan. Pengadaan bisnis kreatif sekaligus perluasan lapangan kerja menunjukkan bahwa UMKM memiliki kontribusi penting dalam peningkatan perekonomian. (Hafsah, 2004)

Berdasarkan permasalahan yang terjadi, maka pemerintah mengambil tindakan untuk melindungi para pelaku UMKM, salah satunya adalah mengesahkan Perppu Nomor 1 Tahun 2020 tentang kebijakan keuangan untuk mengatasi pandemi. Pemerintah juga menganggarkan dana sebesar 405,1 triliun untuk perekonomian yang terdampak adanya pandemi ini. Dari total dana tersebut ada 70,1 triliun untuk membantu UMKM yang rugi atau bahkan gulung tikar karena social dan physical distancing yang diterapkan untuk mencegah penyebaran COVID-19.

\section{KESIMPULAN}

Berdasarkan hasil penelitian, maka didapat bahwa terdapat empat dampak yang diakibatkan dari penyebaran virus Corona bagi UMKM di Kabupaten Sukoharjo. Pertama, penyebaran virus ini mengakibatkan terhentinya perekonomian UMKM. Kedua, terkendalanya kesehatan dari para pelaku UMKM. Ketiga, terbatasnya akses bagi para pelaku UMKM untuk memasarkan produknya ke luar kota ataupun ke luar negeri. Keempat, adalah terpacunya para pelaku usaha UMKM untuk menciptakan peluang usaha baru untuk bisa bertahan dari krisis akibat corona. Atas dasar itu pemerintah menganggarkan dana sebesar 405,1 triliun untuk membantu para pelaku ekonomi 
sekaligus mengentaskan para pelaku

UMKM dari keterpurukan karena Corona.

\section{DAFTAR PUSTAKA}

Darwanto. (2013). Peningkatan Daya Saing UMKM Berbasis Inovasi dan Kreativitas (Strategi Penguatan Property Right terhadap Inovasi dan Kreativitas). Jurnal Bisnis dan Ekonomi, 20, 142-149.

Suharto, Edi (2009). Masyarakat Memberdayakan Rakyat: Kajian Strategis Pembangunan Kesejahteraan Sosial Dan Pekerjaan Sosial. Bandung, PT Refika Aditama.

Kemenkes (2020). Pedoman Kesiapsiagaan Menghadapi Coronavirus. Jakarta: Kementerian Kesehatan Republik Indonesia.

Symond, Denas. (2009). Epidemiologi Terpadu Avian Influenza (Flu Burung) Berbasis Tindakan Kesehatan Masyarakat dalam Respon Pandemi Influenza. Jurnal Bisnis dan Ekonomi, 4 (1), 37-41.

D, S., \& Preswari. (2011). Strategi Pengembangan Industri Kreatif untuk Meningkatkan Daya Saing Pelaku Ekonomi Lokal. Jurnal Aplikasi Manajemen, 9, 301-308.

Hafsah, M. Jafar. (2004). Upaya Pengembangan Usaha Kecil dan Menengah (UKM). Diakses pada tanggal 9 April 2020 pukul 15.17 WIB dari www.smecda.com.

Huberman dan Miles. (1992). Analisa Data Kualitatif, Jakarta: Universitas Indonesia Press. 